Jurnal Hukum Mimbar Justitia

Fakultas Hukum Universitas Suryakancana

Vol. 6 No. 1 - Juni 2020, hlm. 56-70.

ISSN: 2477-5681 (Cetak), ISSN: 2580-0906 (Online)

Open Access at: https://jurnal.unsur.ac.id/jmj

\title{
PERENCANAAN PEMBANGUNAN DAERAH \\ DALAM ERA OTONOMI DAERAH
}

\author{
Saeful Kholik \\ Universitas Wiralodra \\ Email : saefulkholik21@gmail.com
}

Masuk: Maret 2020

Penerimaan: April 2020

Publikasi: Juni 2020

\section{ABSTRAK}

Undang-Undang Nomor 23 Tahun 2014 Tentang Pemerintahan Daerah secara tegas menghendaki agar dalam era sistem pemerintahan daerah ini yang sentralistik menuju desentralistik, pemerintah daerah dan masyarakat serta seluruh komponen stakeholder. Pemerintah harus mampu mengarahkan berbagai kebijakan dalam wujud kerangka implementasi kebijakan otonomi daearh pada suatu titik percepatan kesejahteraan masyarakat melalui peningkatan pelayanan publik dan optimalisasi peran serta masyarakat dalam proses berjalanya otonomi daerah dalam pembangunan.

Penulis dalam penelitian ini ingin menelaah dan menganalisa lebih lanjut tentang urgensi perencanaan pembangunan daerah dalam era otonomi daerah serta hambatan dan strategi pelaksanan rencana pembangunan daerah dalam era otonomi daerah

Metode penelitian yang digunakan adalah penelitian hukum normatif, yaitu penelitian hukum yang dilakukan dengan cara meneliti bahan pustaka atau bahan hukum sekunder sedangkan pendekatan masalah dilakukan dengan menggunakan pendekatan undang-undang dan pendekatan konseptual.

Perencanaan pembangunan dalam suatu negara atau masyarakat yang dapat diusahakan mulai dari ekonomi, sumber daya alam, sumber daya manusia dan infrastruktur karena output dari perencanaan pembangunan daerah adalah pemerintah daerah haruslah mendorong agar tercapainya sebuah rencana pembangunan yang berdasarkan perencanaan daerah. Penyusunan rencana akan sealalu menghadapi hambatan-hambatan dalam bentuk ketidakmauan dan ketidakmampuan penyusun rencana menangkap filosofi dan otonomisasi daerah

Kata Kunci : Pemerintahan Daerah, Kebijakan, Perencanaan Pembangunan

\section{ABSTRACT}

Law Number 23 Year 2014 concerning Regional Government expressly wants that in this era of centralized regional government system towards decentralization, regional government and the community as well as all stakeholder components. The government must be able to direct various policies in the form of a framework for the implementation of regional autonomy policies at a point of accelerating the welfare of 
society through improving public services and optimizing the participation of the community in the process of regional autonomy in development.

The author in this study wants to examine and analyze further the urgency of regional development planning in the era of regional autonomy and the obstacles and strategies for implementing regional development plans in the era of regional autonomy.

The research method used is normative legal research, namely legal research carried out by examining library materials or secondary legal materials while the problem approach is carried out using a legal approach and conceptual approach.

Development planning in a country or society that can be cultivated starting from the economy, natural resources. Human Resources and Infrastructure because the output of regional development planning is that local governments must encourage the achievement of a development plan based on regional planning. The preparation of the plan will always face obstacles in the form of unwillingness and the inability of the compiler to capture the philosophy and autonomization of the region

Keywords: Regional Government, Policy, Development Planning.

\section{PENDAHULUAN}

Negara Hukum adalah konsep yang merupakan produk sejarah. Karena itu unsur-unsur negara hukum mempunyai hubungan yang sangat erat dengan sejarah dan perkembangan masyarakat dari suatu negara. Sementara itu sejarah dan perkembangan masyarakat setiap negara tidaklah sama, sehingga pemaknaan dan unsur-unsur negara hukumnya juga berbeda. Hukum merupakan suatu alat untuk menjalankan sebuah negara melalui kekuasaan. ${ }^{1}$ Maka dalam menjalankan

1 Dedi Mulyadi dan M. Rendi Aridhayandi, 2015, Putusan Mahkamah Konstitusi Tentang Pemilu Serentak Dihubungkan segala kehidupan bernegara harus sesuai dengan aturan hukum yang berlaku demi terciptanya suatu ketertiban hukum dalam masyarakat. Hal ini sesuai dengan istilah Negara Indonesia sebagai Negara hukum (Rechstaat) yang berdasarkan pada Pancasila. $^{2}$

Hukum sebagai institusi sosial, adalah hukum lebih dari pada suatu sistem peraturan belaka, melainkan juga menjalankan fungsi-fungsi sosial

Dengan Pencegahan Korupsi Politik, Jurnal Hukum Mimbar Justitia, Vol. 1 No.2, Fakultas Hukum Universitas Suryakancana, Cianjur, hlm. 537.

2 Dedi Mulyadi, 2012, Kebijakan Legislasi tentang Sanksi Pidana Pemilu Legislatif di Indonesia dalam Perspektif Demokrasi, Gramata Publishing, Jakarta, hlm. 19. 
Saeful Kholik

Jurnal Hukum Mimbar Justitia

Vol. 6 No. 1 - Juni 2020

dalam dan untuk masyarakatnya, seperti mengintegrasikan perilaku dan kepentingan para anggota masyarakat. ${ }^{3}$

Untuk mencapai tujuan negara tersebut, khususnya untuk memajukan atau meningkatkan kesejahteraankemakmuran rakyat, maka Pemerintah Indonesia melaksanakan pembangunan. Dalam melaksanakan pembangunan, dilakukan melalui cara pengadaan tanah atau dulu istilahnya pembebasan hak atas tanah (prijsgeving) salah satu cara pengambilan tanah oleh negara, cara yang lain yaitu pencabutan hak atas tanah onteigening). ${ }^{4}$

Selain itu pernyataan bahwa Negara Indonesia adalah negara hukum juga dapat dilihat dalam penjelasan Undang-Undang Dasar 1945 sebelum perubahan hukum merupakan tatanan kehidupan nasional baik dalam bidang politik, ekonomi, sosial budaya, dan

3 Dwidja Priyatno dan M. Rendi Aridhayandi, 2016, Resensi Buku (Book Review) Satjipto Rahardjo, Ilmu Hukum, Bandung: PT. Citra Aditya, 2014, Jurnal Hukum Mimbar Justitia, Vol. II No. 02, Fakultas Hukum Universitas Suryakancana, Cianjur, hlm. 884.

4 Abdurrahman, 1991, Masalah Pencabutan Hak-Hak Atas Tanah dan Pembebasan Tanah di Indonesia, Edisi Revisi, Citra Aditya Bakti, Bandung, hlm. 10. pertahanan dan keamanan, Dan termasuk Hukum Pemerintahan daerah dan Otonomi Daerah.

Pasal 18 Undang-Undang Dasar 1945 Pada Ayat 1 Dan 2 menyebutkan bahwa Negara Republik Indonesia di bagi atas Provinsi, Kabupaten, dan Kota yang mengatur dan mengurus sendiri urusan pemerintahan menurut asa otonomi dan pembantuan. Pencantuman tentang emerintah Daerah di dalam perubahan UndangUndang Dasar Negara Republik Indonesia Tahun 1945 dilatar belakangi oleh kehendak untuk menampung semangat otonomi daerah dalam memperjuangkan kesejahteraan masyarakat daerah. Hal itu dilakukan setelah belajar dari praktik ketatanegaraan pada era sebelumnya yang cenderung sentralistis. ${ }^{5}$

Otonomi daerah mempunyai suatu tujuan tersendiri guna memberikan percepatan kesejahteraan rakyat yang ada didaerah agar merata baik secara pengelolaan sumber daya alam dan sumber daya manusianya itu

5 Azhary, 1995, Negara Hukum Indonesia, Analisis Yuridis Normatif Tentang UnsurUnsurnya, UI Press, Jakarta, hlm. 23. 
Saeful Kholik

Jurnal Hukum Mimbar Justitia

Vol. 6 No. 1 - Juni 2020

sendiri, Dalam pelaksanaan otonomi daerah maka daerah mempunyai kewenangan untuk mengatur dan mengurus daerahnya sesuai dengan potensi daerah tersebut, $\mathrm{Hal}$ ini termasuk mengatur tentang perencaan pembangunan yang ada didaerah guna pemerataan kesejahteraan rakyat.

Munculnya otonomi daerah yang memberikan persoalan dan keluasaan kepada daerah untuk membangun daerahnya menjadi titik sorot yang sangat tajam terhadap bagaimana otonomi daerah dalam pembangunan mampu berjalan atau tidaknya pembangunan di daerah sesuai dengan kebutuhan dalam daerah tersebut.

Persoalaan pembangunan daerah otonom dapat dilihat dari sebuah kinerja dapat dilihat dari sebuah indeks kualitas manusia yang mampu diukur secara nyata sebagai subjek dari pembangunan itu sendiri, klasifikasi dari indeks keseluruhan atau universal ini mampu diukur secara tingkat kualitas manusia suatu bangsa meliputi pendidikan, kesehatan, dan percepatan pembangunan daerah otonom. ${ }^{6}$

Melalui Undang-Undang Nomor 17 Tahun 2007 tentang Sistem Perencanaan Pembangunan Nasional, pemerintah dapat meletakan sebuah komitmen hukum dan politik untuk dapat memperbaiki kualitas pembangunan nasional dan daerah, Impelentasi yang baik dari sebuah keseluruhan komponen peraturan dan subjek hukum inilah yang dapat dilakukan secara konsisten maka akan tercapainya suatu pembangunan yang secara merata dan percepatan dalam sistem otonomi daerah yang menjadi tolak ukur daerah dalam melaksanakan pembangunan secara keberlanjutan.

Melalui Undang-Undang Nomor 23 Tahun 2014 tentang Pemerintahan Daerah, secara tegas mengkhendaki agar dalam era sistem pemerintahan daerah ini yang sentralistik menuju desentralistik, pemerintah daerah dan masyarakat serta seluruh komponen stakeholder, Pemerintah harus mampu

6 I Nyoman Sumaryadi, 2005, Perencanaan Pembangunan Daerah Otonom Dan Pemberdayaan Masyarakat, Citra Utama, Bandung, hlm. 5. 
Saeful Kholik

Jurnal Hukum Mimbar Justitia

Vol. 6 No. 1 - Juni 2020

mengarahkan berbagai kebijakan dalam wujud kerangka implementasi kebijakan otonomi daerah pada suatu titik percepatan kesejahteraan masyarakat melalui peningkatan pelayanan publik dan optimalisasi peran serta masyarakat dalam proses berjalanya otonomi daerah dalam pembangunan.

Keseluruhan atau berbagai dokumen dalam sebuah perencanaan pembangunan daerah otonom dalam memperlihatkan sebuah indikasi jangka panjang dan jangka menengah yang mampu mengatur visi dan misi arah tujuan pembangunan. Program kerja kepala daerah dan Organisasi Perangkat Daerah termasuk keuangan daerah, Rencana pembangunan tahunan daerah terdapat dua yaitu RKPD dan Renstra-SKPD memuat suatu kebijakan visi dan misi tujuan, strategi arah kebijakan daerah dalam proses dan berjalannya pembangunan daerah guna mewujudkan percepatan pembangunan daerah. ${ }^{7}$

$$
\text { Implementasinya dalam era }
$$

otonomi daearah ini khusunya tehadap

Ibid, hlm. 8 pembangunan sering sekali menjadi hal yang disepelekan, melihat urgensi dalam percepatan pembangunan daerah inilah menjadi titik awal balik kebijakan pembangunan yang mampu dapat di rasakan oleh masyarakat untuk mendapatkan sebuah kesejahteraan. Dengan identifikasi masalah dalam penelitian ini:

1. Bagaimanakah urgensi perencanaan pembangunan daerah dalam era otonomi daerah?

2. Bagaimanakah hambatan dan strategi pelaksanan rencana pembangunan daerah dalam era otonomi daerah?

\section{PEMBAHASAN}

\section{A. Urgensi}

\section{Perencanaan}

Pembangunan Daerah Dalam Era Otonomi Daerah.

Era otnomi daerah merupakan titik balik guna memberikan kekelulasaan daerah untuk meengatur rumah tangganya sendiri, namun di tengah perkembangan era otonomi daerah ini memberikan peluang untuk daerah membangun daerahnya masing- 
Saeful Kholik

Jurnal Hukum Mimbar Justitia

Vol. 6 No. 1 - Juni 2020

masing, akan tetapi disatu sisi masih banyak yang belum siap terhadap sistem pemerintahan daerah dan otonomi daerah sehingga menyebabkan daerah yang tertinggal dan melupakan sebuah asas perencanaan dalam pembangunan, oleh karena itu dengan urgennya untuk mengejar ketertinggalan percepatan pembangungan daerah dibutuhkan sebuah perencanaan dan pembangunan. Hal ini lah mendorong Urgensinya perencanaan dalam pembangunan daerah.

Kesenjangan pembangunan merupakan permasalahan yang kompleks dihadapi negara Indonesia. Permasalahan kesenjangan yang paling mencuat di Indonesia antara lain kesenjangan antar daerah, antar sektor, antar wilayah antara Kawasan Barat Indonesia dengan Kawasan Timur Indonesia, antara perkotaan dan perdesaan. Kesenjangan tersebut tidak hanya dipandang dari aspek ekonomi, tapi juga aspek non ekonomi termasuk pemabangunan dalam era otonomi daerah. Bentuk kesenjangan yang beberapa periode belakangan ini menjadi isu penting di Indonesia, telah menghasilkan suatu konsekuensi berupa pemusatan hasil pembangunan pada sebagian wilayah.

\section{Albert Waterson menyebutkan} bahwa perencanaan pembangunan adalah melihat ke depan mengambil pilihan berbagai alternatif dari kegiatan untuk mencapai tujuan masa depan tersebut dengan terus mengikuti agar supaya pelaksanaannya tidak menyimpang dari tujuan.

\section{Widjojo Nitisastro menyatakan} bahwa "Perencanaan pembangunan pada dasarnya berkisar kepada dua hal Yang pertama ialah penentuan pilihan secara sadar mengenai tujuan-tujuan konkret yang hendak dicapai dalam jangka waktu tertentu atas dasar nilainilai yang dimiliki masyarakat yang bersangkutan Yang kedua ialah pilihan diantara cara-cara alternatif yang effisien serta rasional guna mencapai tujuan-tujuan tersebut" ${ }^{8}$

Perencanaan yang baik dan benar adalah suatu perencanaan yang dapat

8 Kuncoro,M, Otonomi Dan Pembangunan Daerah :Reformasi.Perencanaan,Strategi Dan Peluang, Erlangga, Jakarta, 2005, hal. 10. 
Saeful Kholik

Jurnal Hukum Mimbar Justitia

Vol. 6 No. 1 - Juni 2020

dilakukan berdasarkan basic on data dan informasi yang akurat, valid dan mampu menggunakan asas kepastian yang mampu mempertimbangkan sumber daya dan potensi yang ada dan dimiliki oleh daerah tersebut, Guna proses penyusunan perencaan daerah haruslah mampu mengkaji terlebih dahulu faktor-faktor perkembangan di daerah salah satunya Indeks Pembangunan Manusia itu sendiri.

\section{Urgensi perencanaan}

pembangunan dalam bidang permasalahan pembangunan dalam suatu Negara atau masyarakat yang dikaitkan dengan sumber-sumber pembangunan yang dapat diusahakan Misalnya ekonomi, sumber daya alam, sumber daya manusia, infrastruktur dan sebagainya. Alasan pentingnya perencanaan pembangunan suatu daerah atau daerah otonom, yaitu:

a) Perencanaan dilihat dari segi suatu alat atau cara untuk mencapai tujuan dengan lebih baik mendapatkan alasan yang telah kuat untuk melakukan perencanaan b) Dengan adanya perencanaan diharapkan terdapatnya suatu pengarahan kegiatan, adanya pedoman bagi pelaksanaan kegiatan-kegiatan yang ditujukan kepada pencapaian tujuan pembangunan;

c) Dengan perencanaan maka dilakukan suatu perkiraan (forecasting) terhadap hal-hal dalam masa pelaksanaan yang akan dilalui. Perkiraan dilakukan mengenai potensi-potensi dan prospek-prospek perkembangan tetapi juga mengenai hambatanhambatan dan resiko-resiko yang mungkin dihadapi. Perencanaan mengusahakan supaya ketidakpastian dapat dibatasi sedikit mungkin.

d) Perencanaan memberikan kesempatan untuk memilih berbagai alternatif tentang cara yang terbaik (the best alternative) atau kesempatan untuk memilih kombinasi cara yang terbaik ( the best combination).

e) Dengan perencanaan dilakukan penyusunan skala prioritas. 
Saeful Kholik

Jurnal Hukum Mimbar Justitia

Vol. 6 No. 1 - Juni 2020

\section{Memilih urutan-urutan dari segi pentingnya suatu tujuan, sasaran maupun kegiatan usaha; \\ f) Dengan adanya rencana maka akan ada suatu alat pengukur atau standar untuk mengadakan pengawasan evaluasi (control atau evaluation).}

Perencanaan pembangunan di daerah otonom harus memperhatikan adanya sinkronisasi, koordinasi dan integrasi dengan perencanaan pembangunan nasional. Karena capaian tujuan pembangunan daerah harus bersifat mendukung pencapaian tujuan pembangunan secara nasional. ${ }^{9}$

Perencanaan pembangunan berpacu dan berfokus utamanya terhadap Undang-Undang Nomor 17 Tahun 2007 tentang Perencanaan Pembangunan Nasional memerlukan perencanaan pembangunan jangka panjang sebagai arah dan prioritas pembangunan secara menyeluruh yang akan dilakukan secara bertahap untuk mewujudkan masyarakat adil dan

9 Riyadi Dan Deddy S.B, 2004, Perencanaan pembangunan Daerah :Strategi Menggali Potensi Dalam Mewujudkan Otonomi Daerah, Gramedia Pustaka Utama, Jakarta, hlm. 33. makmur sebagaimana diamanatkan oleh Undang-Undang Dasar Negara Republik Indonesia Tahun 1945.

Pasal 13 ayat (1) Undang-Undang Nomor 25 Tahun 2004 tentang Sistem Perencanaan Pembangunan Nasional mengamanatkan

Rencana Pembangunan Jangka Panjang Nasional yang ditetapkan dengan Undangundang yang satu kesatuan dalam tata cara perencanaan pembangunan untuk menghasilkan rencana-rencana pembangunan dalam jangka panjang, jangka menengah, dan tahunan yang dilaksanakan oleh unsur penyelenggara ne gara dan masyarakat di tingkat Pusat dan Daerah.

Output dari perencanaan pembangunan daerah adalah pemerintah daerah haruslah mendorong agar tercapainya sebuah rencana pembangunan yang berdasarkan perencanaan daerah karena perencanaan merupakan hal yang terpenting dalam pembangunan daerah karena sebuah keharusan hal ini dikarenakan urgensinya untuk perencanaan pembangunan daerah. 
Saeful Kholik

Jurnal Hukum Mimbar Justitia

Vol. 6 No. 1 - Juni 2020

\section{B. Hambatan Dan Strategi \\ Pelaksanan \\ Pembangunan Daerah Dalam Era}

Otonomi Daerah.

Rencana ataupun persiapan

dalam pelaksanaan rencana

pembangunan daerah memang

haruslah mempersiapkan diri dengan

baik, Rencana awal persiapan yang baik

belum tentu menghasilkan sebuah

kebijakan atau bahkan hasil yang baik

sesui apa yang diharapkan dalam

perencaan daerah tersebut.

Hal ini dapat di pandang dan dianalisis karena sebuah model sebuah proses manajemen pembangunan daerah yang terkadang tidak disesuakan dengan kemapuan daerah tersebut, Disisi lain perencanaan terdapat fungsi-fungsi lainnya, Fungsi tersbut tidaklah lain adalah sebuah kepemimpinan, pengawasan, keterbukaan, suatu pembangunan dikatakan gagal atau tidak berjalan dalam mencapai suatu tujuannya dalam jangka pendek maupun jangka panjang apabila dalam implementasinya dalam suatu daerah fungsi-fungsi yang terkait dalam system perencanaan pembangunan daerah tidak saling keterkaitan dan tidak dijalankan tidak baik.

Pencapaian dalam pelaksanaan fungsi-fungsi secara baik tidak bisa dilihat arahnya dari kepemimpinan yang baik saja akan tetapi semua komponen yang mampu berjalan dengan baik dan benar secara koordinasi bersama-sama dalam sebuah prinsip penerapan perencanaan dan pembnagunan daerah, Salah satu ciri dalam daerah yang tidak maju bisa diihat dari sebuah pemimpin yang mematikan salah satu fungsi dari sebuah koordinasi satu sama lainya dalam fungsi pengawasan terhadap pembangunan (Daerah Otonom), Maka dapat dipastikan prinsip dan perencanaan tidak berjalan dengan optimal.

Disuatu sisi sangat perlu menjaga sinkornisasi dalam menjalankan sebuah fungsi-fungsi manajamen pembangunan daerah, Haruslah mampu disadari perencanaan pembangunan daerah telah disusun dengan baik dan benar berdasarkan kerangka pemikiran dasar 
Saeful Kholik

Jurnal Hukum Mimbar Justitia

Vol. 6 No. 1 - Juni 2020

pembangunan daerah yang baik dan telah memalui tahapan yang sudah sesuai dengan tahapan yang telah disepakati, kritik dan evaluasi akan tetapi suatu perencaan haruslah mampu terbuka dalam hal perencanaan dan pembangunan daerah apabila terjadi perubahan apabila diperlukan, Implementasinya dalam asas keperluan dilakukan perubahan maka unsur dan komponen harus mampu melakukan perubahan tersebut dan tidak terjadinya keraguan perubahan perencanaan dan pembangunan daerah.

Di Lain hal keterbukaan dan pengawasan sangat diperlukan dalam perencanaan dan pembangunan suatu daerah maka daerah harus mampu keterbukaan terhadap rencana variasi peran badan resmi yang mampu mengawasai pelaksanaan perencanaan yang mampu diandalkan, Maka pemerintah haruslah membentuk badan yang mampu berisikan sebuah praktisi dan pakar yang berstatus independen dalam sebuah penyusunan dan perencaan pembangunan daerah dan perencanaan pernyataan- pernyataannya

menyangkut keselarasan dan kesesuaian dengan rencana dan pelaksanaan perencaan dan pembangunan badan yang berisi para pakar dan praktisi karena hal ini merupakan sebuah wujud optimalisasi pembanguan dan perencanaan setelah para perencana dan pakar menyusun sebuah rencana bersama untuk pembnagunnan suatu daerah.

Penyusaain rencana akan sealalu menghadapi hambatan-hambatan baik terduga maupun tidak terduga dalam bentuk :

a) Ketidakmauan dan ketidakmampuan penyusun rencana menangkap filosofi dan otonomisasi daerah.

b) Ketidakmampuan, kelambatan atau ketidakpengalaman sebuah tim perencana dalam menyusun rencana yang baik, sesuai standar dan dapat di mengerti.

c) Buruknya kerangka pemikiran dasar daerah tentang daerah yang bersangkutan.

d) Resistensi anggota tim penyusun rencana dan masyarakat dalam sebuah perencanaan terhadap 
Saeful Kholik

Jurnal Hukum Mimbar Justitia

Vol. 6 No. 1 - Juni 2020

sebuah perubahan haluan
pembangunan atau penggantian
sektor unggulan.
e) Mentalitas dalam memandang
rencana terutama rencana jangka
panjang, sebagai tidak penting
dan hanya memandang sekedar
untuk memenuhi sebuah syarat
yang diharuskan dan digariskan
dalam perencanaan dan
pembangunan daerah. ${ }^{10}$
Filosofi terhadap otonomisasi

daerah merupakan sebuah aura yang memang haruslah ada dan nyata dalam pembentukan dan perencanaan pembagunan daerah, Oleh karena itu kesalahan dalam mengartikan dan mengimplementasikan dapat mengakibatkan arah pembangunan daerah yang menyimpang dan tidak sesuai dengan arah tujuan dan pemandirian. Otonomisasi dapat disalah artikan sebagai sebuah penguasaan daerah sehingga pemerintah daerah mengembangkan keuangan daerahnya. Dalam Implementasinya dalam melaksanakan keungan daerah terkadang sering sekali

10 Ibid, hlm. 72. daerah terjebak dalam kerangka perencanaan atau pengelolaan keuangannya bukan mensejahterakan rakyatnya akan tetapi menyengsarakan dan membebani rakyatnya. ${ }^{11}$

Ketidakmampuan

dan ketidakmauan serta kelambatan dalam menyusun rencana yang sebenar benarnya dapat ditanggulangi dengan meminta arahan terhadap orang dan praktisi atau bahkan pakar dalam perencanaan dan pembangunan daerah yang notabene adalah praktisi dari luar, Namun terkadang hal ini dapat diartikan dengan resistensi yang berbau asing dan luar, Hal ini lah yang akan menjadi sebuah boomerang bagi daerah yang mempunyai perencanan dan pengembangan daerah yang tidak sesuainnya perencanaan dan pembangunan yang buruk.

Terhadap buruknya kerangka pemikiran dalam pengembangan dan perencaan pembangunan daerah yang bersangkutan bisa dikaranakan kelemahan dan ketidakmampuan dalam pengkajian daerah

11 Arsjad, Nurdjaman, Bambang Kusumanto \& Yuwono Prawirsoetoto, 1992, Keuangan Negara, Intermedia, Jakarta, hlm. 70. 
Saeful Kholik

Jurnal Hukum Mimbar Justitia

Vol. 6 No. 1 - Juni 2020

bersangkutan. Hal ini tidak terlepas dari

oleh pandangan bahwa kerangka pemikiran demikian tidak diperlukan. Penyusunan rencana yang sering terlalu percaya diri merasa lebih mengenal dan memahami karakteristik wilayah daerah yang akan progres pembangungan tersebutlah dapat mengabaikan peran kerangka yang mendasar dalam sebuah pembangunan, Akibat kepercaya diri yang berlebihan ini dapat mengabikatkan dengan kerangka pemikiran tdak dapat disusun dengan kepastian dan arah yang pasti akan tetapi akan mendapatkan Output kerangka pemikiran yang basa-basi.

Banyak sekelompok orang menganggap bahwasanya perencanaan merasa cukup adalah perencanaan pekerjaan yang tidak penting dan tidak perlukan, apalagi terkait dengan perencanaan jangka panajang, menengah, dan pendek suatu pembangunan daerah. Tidak sering kali banyak pemimpin yang hanya mampu berfikir dan berpandangan didepan saja dan dekat saja dan tidak berfikir dalam rencana pandangan kedepan, $\mathrm{Hal}$ ini biasanya dapat disebabkan oleh mentalitas yang hanya ingin melakukan sebuah yang mampu memberikan hasil pada kepemimpinnanya (Agency Problem).

Hal ini dapat mampu dicegah dan dikoreksi melalui sebuah praktisi yang berkompenten dalam perencanaan dan pembangunan daerah dan masyarakat secara umumnya terutama masyarakat yang generasi muda yang mampu mendobrak perubahan daerahnya demi kemajuan daerahnya.

Hambatan-hambatan ini harus mampu dicegah dan bila perlu mampu dihilangkan sekalipun pengaruh yang mungkin muncul pada sebuah perencaan khususnya dalam sebuah proses dan manjamen pembangunan daerah dalam system pemerintahan daerah pada umumnya haruslah mampu diminimalisasi, Dalam prakteknya dapat diminimalisasi dengan sebuah prinsip transparan, sehingga apabila terjadi hal-hal yang tidak sesuai maka semua komponen dapat mengetahuinya dan mampu dengan segera menanggulanginya. 
Saeful Kholik

Jurnal Hukum Mimbar Justitia

Vol. 6 No. 1 - Juni 2020

\begin{tabular}{lll}
\hline Hambatan yang ada dapat segera & d) & Evaluasi. \\
di minimalisir dengan sebuah strategi & e) & Feedback Dari perencaan dan \\
dan konsep perencanaan dan & pembangunan daerah. \\
pembnagunan yang ampuh dan jitu & Konsep dari sebuah rencana dan \\
kepada pengelolaan perencanaan dan & strategi dalam perencanan dan \\
pengembangan perencanaan daerah & pembangunan daerah sebgai berikut:
\end{tabular}
dengan mempertibangkan komponen sebgai berikut:
a) Pra Perencanaan.
b) Perencanaan yang matang.
c) Impelentasi dan pengawasan.

Skema Dasar Kaitan Antar Variabel Umum Pembangunan

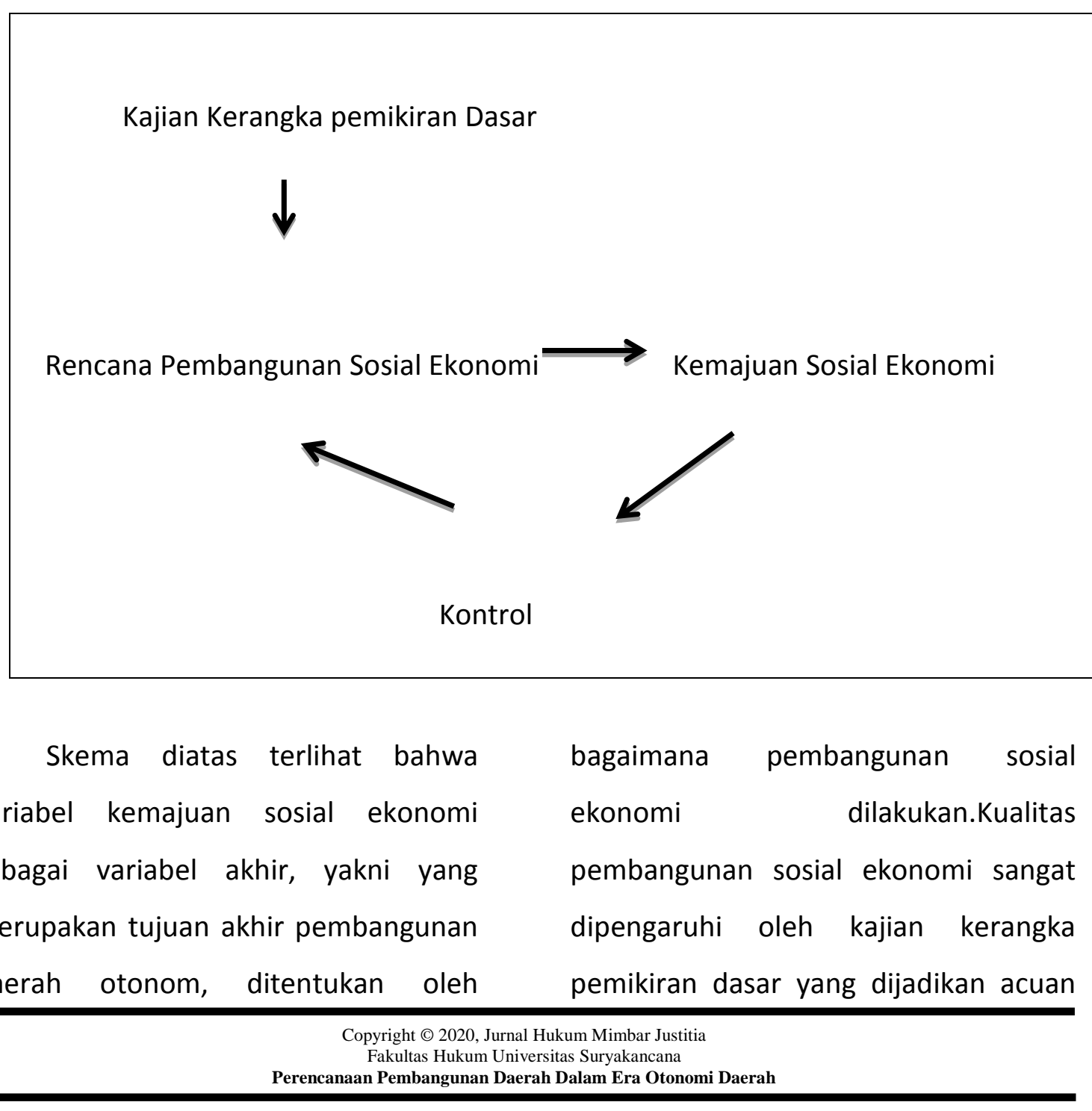


Saeful Kholik

Jurnal Hukum Mimbar Justitia

Vol. 6 No. 1 - Juni 2020

\begin{abstract}
dalam
perumusan

rencana

pembangunan ekonomi. Setelah

kemajuan ekonomi teramati, fungsi

kontrol bisa berperan memberikan

informasi atau umpan balik pada

perencanaan dan pelaksanaan

pembangunan periode berikutnya,

selain kontrol itu sendiri melekat pada

setiap pelaksanaan langkah-langkah

pembangunan sesuai dengan yang

direncanakan. Tampak jelas bahwa

semua bagian dalam skema diatas

berperilaku sebagai variabel umun yang

berat kualitasnya selain ditentukan oleh

manusia dan kondisi lingkungan

regional, nasional dan internasional

(perencana, pelaksana, kondisi

perekonomian nasional, dan lain-lain)

juga turut menentukan kualitas bagian

yang lain. Variabel -variabel umum ini

perlu diuraikan lebih lanjut menjadi variabel yang saling berkaitan satu dengan yang lainnya. ${ }^{12}$
\end{abstract}

12 Tjokroamidjojo, H. Bintoro \& Mustopadijaja, $\mathrm{tt}$, Teori Dan Strategi \& Pembangunan Nasional, Haji Masagung, Jakarta, hlm. 80.

\section{PENUTUP}

\section{A. Kesimpulan}

Urgensi

perencanaan

pembangunan dalam bidang

Permasalahan pembangunan dalam

suatu negara atau masyarakat yang dikaitkan dengan sumber-sumber pembangunan yang dapat diusahakan Misalnya ekonomi, sumber daya alam. sumber daya manusia, infrastruktur karena output dari perencanaan pembangunan daerah adalah pemerintah daerah haruslah mendorong agar tercapainya sebuah rencana pembangunan yang

berdasarkan perencanaan daerah karena perencanaan merupakan hal yang terpenting dalam pembangunan daerah.

Penyesuaian rencana akan selalu menghadapi hambatan-hambatan baik terduga maupun tidak terduga dalam bentuk Ketidakmauan dan ketidakmampuan penyusun rencana menangkap filosofi dan otonomisasi daerah. Ketidakmampuan, kelambatan atau ketidak pengalaman sebuah tim perencana dalam menyusun rencana yang baik, sesuai standar dan dapat di 
Saeful Kholik

Jurnal Hukum Mimbar Justitia

Vol. 6 No. 1 - Juni 2020

mengerti, Buruknya kerangka

pemikiran dasar daerah tentang daerah yang bersangkutan, Resistensi anggota tim penyusun rencana dan masyarakat dalam sebuah perencanaan terhadap sebuah perubahan haluan pembangunan atau penggantian sektor unggulan, Mentalitas dalam memandang rencana terutama rencana jangka panjang.

\section{B. Saran}

Perencanaan dan pembangunan merupakan hal yang sangat utama dalam salah satu indikator perkembangan daerah di Era pemerintahan daerah dan otonomi daerah ini, Akan tetapi dalam era ini haruslah berpacu pada prinsip perencanaan dan pembangunan daerah dalam jangak panjang. Menengah dan pendek guna mencapai tujuan itu sendiri, akan tetapi di tengah urgensi perencanaan dan pembangunan daerah haruslah kembali pada rencana dan penanggulanagan perencanaan dan pembangungan serta keterbukaan sehingga daerah dalam menentukan kebijakan dan perencanaan pembangunan tidak salah jalan dan tetap selaras.

\section{DAFTAR PUSTAKA}

A. Buku.

Arsjad, Nurdjaman, Bambang Kusumanto \& Yuwono Prawirsoetoto, 1992, Keuangan Negara, Intermedia, Jakarta.

Azhary, 1995, Negara Hukum Indonesia, Analisis Yuridis Normatif Tentang UnsurUnsurnya, UI Press, Jakarta.

Dedi Mulyadi, 2012, Kebijakan Legislasi tentang Sanksi Pidana Pemilu Legislatif di Indonesia dalam Perspektif Demokrasi, Gramata Publishing, Jakarta.

I Nyoman Sumaryadi, 2005, Perencanaan Pembangunan Daerah Otonom Dan Pemberdayaan Masyarakat, Citra Utama, Bandung.

Kuncoro,M, 2005, Otonomi Dan Pembangunan Daerah :Reformasi Perencanaan, Strategi Dan Peluang, Erlangga, Jakarta.

Riyadi Dan Deddy S.B, 2004, Perencanaan pembangunan Daerah :Strategi Menggali Potensi Dalam Mewujudkan Otonomi Daerah, Gramedia Pustaka Utama, Jakarta. 
Saeful Kholik

Jurnal Hukum Mimbar Justitia

Vol. 6 No. 1 - Juni 2020

Tjokroamidjojo, H. Bintoro \&

Mustopadijaja, tt, Teori Dan

Strategi \& Pembangunan

Nasional, Haji Masagung, Jakarta.

\section{B. Peraturan Perundang-Undangan.}

Undang-Undang Dasar Negara Republik Indonesia Tahun 1945.

Undang-Undang Nomor 23 Tahun 2014

Tentang Pemerintahan Daerah.

Undang-Undang Nomor 17 Tahun 2007 tentang Sistem Perencanaan Pembangunan Nasional.

C. Jurnal.

Dedi Mulyadi dan M. Rendi Aridhayandi, 2015, Putusan Mahkamah Konstitusi Tentang Pemilu Serentak Dihubungkan Dengan Pencegahan Korupsi Politik, Jurnal Hukum Mimbar Justitia, Vol. 1 No.2, Fakultas Hukum Universitas Suryakancana, Cianjur.

Dwidja Priyatno dan M. Rendi Aridhayandi, 2016, Resensi Buku (Book Review) Satjipto Rahardjo, Ilmu Hukum, Bandung: PT. Citra Aditya, 2014, Jurnal Hukum Mimbar Justitia, Vol. 2 No. 02, Fakultas Hukum Universitas Suryakancana, Cianjur. 